\title{
Routine Histopathological Evaluation After Appendectomy: Is It Necessary? A Systematic Review
}

\author{
Kashish Malhotra ${ }^{1}$, Ashvind Bawa ${ }^{1}$ \\ 1. General Surgery, Dayanand Medical College and Hospital, Ludhiana, IND
}

Corresponding author: Kashish Malhotra, drkashishmalhotra@gmail.com

\begin{abstract}
Acute appendicitis is one of the most common reasons for acute abdominal pain. Fecaliths and lymphoid hyperplasia are the usual etiology of acute appendicitis, however, other unusual causes can also not be neglected which can be parasitic infections, benign or malignant lesions. Due to substantial lab costs and limited resources, the policy of routine histopathological examination (HPE) of appendectomy samples is being questioned.
\end{abstract}

PubMed, PubMed Central (PMC), and Google Scholar were used to look for relevant published studies. The following keywords were used both alone and in combination: "Acute appendicitis" and "routine histopathological examination”. Fifteen articles were selected for final review that collectively had 57,524 cases. All these studies included in this systematic review are peer-reviewed.

Based on the reviewed articles, it was found that though the probability of unusual findings in a patient of acute appendicitis is less but it is still significant and if found, often results in a change of management plan of the patient.

Therefore, it is recommended to perform a routine histopathological examination of all appendectomy specimens to rule out unusual pathologies.

Categories: Gastroenterology, General Surgery

Keywords: appendectomy, appendicitis

\section{Introduction And Background}

Acute appendicitis is referred to as inflammation of the inner lining of the appendix, which then may advance to other parts of the organ and surrounding areas. Obstruction of the lumen is one of the major causative factors behind this pathology which can be due to a variety of reasons. Fecaliths and lymphoid hyperplasia are the usual etiology of this clinico-pathological condition, however, other unusual causes can also not be neglected which can be benign neuroma, mucocele, mucinous cystadenoma, endometriosis, gastrointestinal stromal tumor, carcinoid tumors of the appendix, hyperplastic polyp, lymphoma, leukemia, diverticulitis, granulomatous diseases, or infections say amebiasis, enterobiasis, actinomycosis, balantidiasis, schistosomiasis, trichuriasis, or tuberculosis (TB) [1].

Malhotra et al. This is an open access article distributed under the terms of the Creative Commons Attribution License CC-BY 4.0, which permits unrestricted use, distribution, and reproduction in any medium, provided the original author and source are credited.

Acute appendicitis is one of the most common reasons for acute abdominal pain. Though it can occur in any age group, it is quite frequently seen between the ages of 10 and 20 years. The lifetime risk for males is $8.6 \%$ and for females is $6.7 \%$ in the United States [2].

The clinical features which primarily put suspicion at diagnosis of acute appendicitis in adults are right lower quadrant pain, abdominal rigidity, and radiation of periumbilical pain to the right lower quadrant. In children, absent or decreased bowel sounds, a positive Psoas sign (pain on passive extension of the right thigh), a positive Rovsing sign (palpation of the left lower quadrant of abdomen intensifies the pain felt in the right lower quadrant), positive Obturator sign (pain on passive internal rotation of the flexed thigh) help in ruling in the diagnosis in favor of acute appendicitis [3].

Surgical appendectomy is the mainstay treatment of acute appendicitis which can be performed either as an open surgery or laparoscopic (minimally invasive) procedure. A recent meta-analysis of randomized controlled trials comparing postoperative results of laparoscopic and open surgery showed that there is lesser postoperative complications, lower incidence of wound infection, shorter duration of stay, and a comparatively faster return to normal activity in favor of laparoscopic operation and a smaller operation time in favor of open surgery via a limited right lower quadrant incision [4].

The protocol of sending appendectomy specimens for histopathological examination (HPE) is variable in various hospitals. This article presents a systematic review from various studies to provide a better basis for 


\section{Cureus}

assessing the frequency of unusual findings in appendectomy specimens and whether a routine HPE of appendectomy specimens is needed.

\section{Review}

\section{Materials and methods}

On the basis of Preferred Reporting Items for Systematic Reviews and Meta-Analyses (PRISMA) guidelines [5], a thorough literature search was conducted using PubMed, PubMed Central (PMC), and Google Scholar for the relevant published studies using the following keywords both alone and in combination: "Acute appendicitis" and "routine histopathological examination".

\section{Inclusion/Exclusion Criteria}

Papers from 2000 till June 2020 in the English language were screened. Research papers in other languages and duplicate papers were not included. Only peer-reviewed articles were included and grey literature was not included. PRISMA diagram depicting the selection and screening of records is shown in Figure 1.

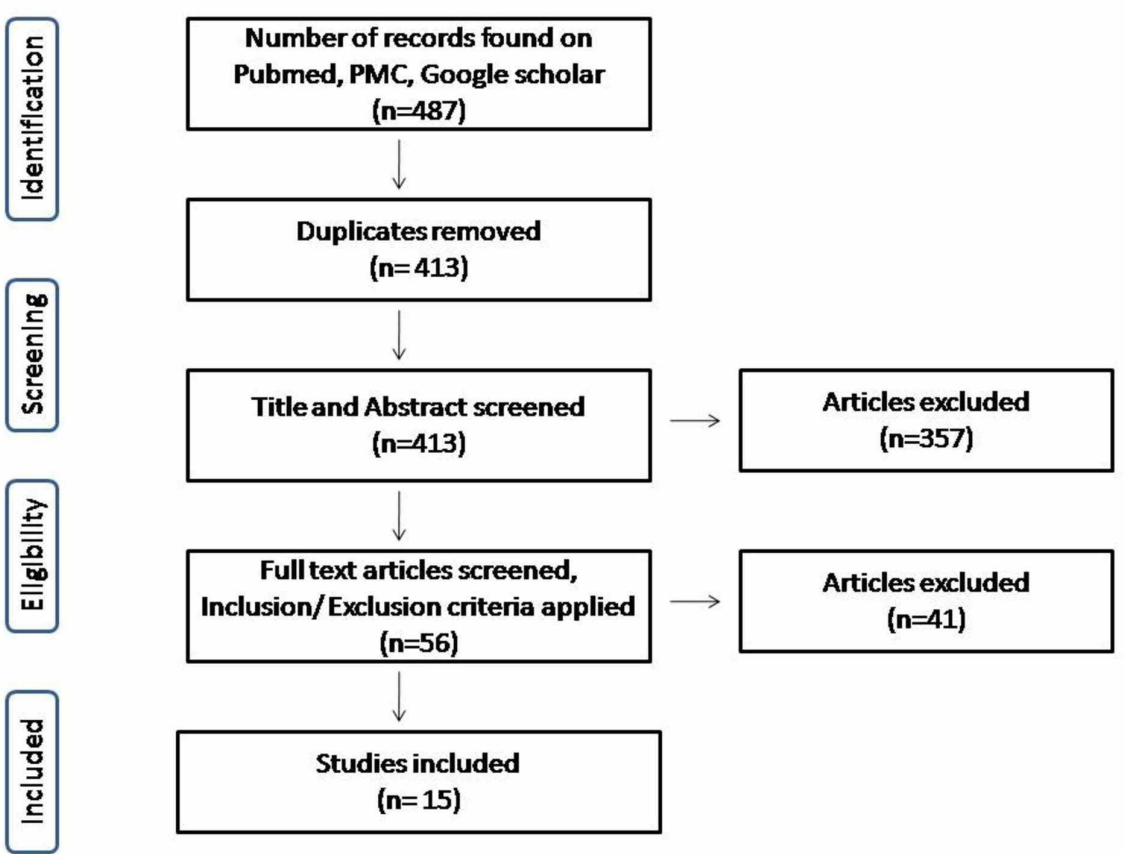

FIGURE 1: PRISMA diagram showing selection of data

\section{Results}

After applying the above-mentioned search criteria, 15 articles were selected for the final review that collectively had 57,524 cases. All these studies included in this systematic review are peer-reviewed.

Details of the studies and relevant related details are summarized in Table 1 . 


\section{Cureus}

\begin{tabular}{|c|c|c|c|c|}
\hline $\begin{array}{l}\text { Author name } \\
\text { and year of } \\
\text { publication }\end{array}$ & Study type & $\begin{array}{l}\text { No. of } \\
\text { patients }\end{array}$ & Study purpose & Result/Conclusion \\
\hline $\begin{array}{l}\text { Elfaedy et al., } \\
2019[6]\end{array}$ & Retrospective & 4,012 & $\begin{array}{l}\text { To investigate the role of routine HPE of } \\
\text { appendectomy samples and its further } \\
\text { impact on the management of patients }\end{array}$ & $\begin{array}{l}\text { HPE confirms an unusual diagnosis which } \\
\text { has an impact on patient's management }\end{array}$ \\
\hline $\begin{array}{l}\text { Unver et al., } \\
2019[7]\end{array}$ & Retrospective & 2,047 & $\begin{array}{l}\text { To show the efficacy of HPE of } \\
\text { appendectomy samples in making a } \\
\text { diagnosis }\end{array}$ & $\begin{array}{l}\text { Though small but significant }(1.66 \%) \\
\text { number of unusual findings was seen } \\
\text { suggesting routine HPE }\end{array}$ \\
\hline $\begin{array}{l}\text { Dincel et al., } \\
2018[8]\end{array}$ & Retrospective & 1,970 & $\begin{array}{l}\text { To find the frequency of unexpected } \\
\text { pathologies in their hospital and compare } \\
\text { the results }\end{array}$ & $\begin{array}{l}\text { Unusual pathologies are often overlooked } \\
\text { if routine HPE is not done }\end{array}$ \\
\hline $\begin{array}{l}\text { Omiyale \& } \\
\text { Adjepong, } \\
2015[9]\end{array}$ & Retrospective & 238 & $\begin{array}{l}\text { To correlate clinical and pathological } \\
\text { diagnosis of acute appendicitis }\end{array}$ & $\begin{array}{l}\text { Unusual pathologies usually impact the } \\
\text { management of patient }\end{array}$ \\
\hline $\begin{array}{l}\text { Yabanoglu et al., } \\
2014 \text { [10] }\end{array}$ & Retrospective & 1,466 & $\begin{array}{l}\text { To assess unusual pathologies by HPE of } \\
\text { appendectomy specimen }\end{array}$ & $\begin{array}{l}\text { Parasitic infection was the most frequently } \\
\text { associated unusual pathology }\end{array}$ \\
\hline $\begin{array}{l}\text { Charfi et al., } \\
2014 \text { [11] }\end{array}$ & Retrospective & 24,697 & $\begin{array}{l}\text { To analyze the necessity of routine HPE of } \\
\text { appendectomy specimen }\end{array}$ & $\begin{array}{l}\text { Though routine HPE is not cheap but still } \\
\text { due to the probability of unusual } \\
\text { diagnosis, routine HPE is recommended }\end{array}$ \\
\hline $\begin{array}{l}\text { Yilmaz et al., } \\
2013 \text { [12] }\end{array}$ & Retrospective & 1,621 & $\begin{array}{l}\text { To understand the implications of unusual } \\
\text { HPE findings in appendectomy patients }\end{array}$ & $\begin{array}{l}\text { HPE helps in relatively early diagnosis and } \\
\text { management in unusual cases }\end{array}$ \\
\hline $\begin{array}{l}\text { Emre et al., } \\
2013 \text { [13] }\end{array}$ & Retrospective & 1,255 & $\begin{array}{l}\text { To analyze the benefit of routine HPE in } \\
\text { appendicitis patients clinically }\end{array}$ & $\begin{array}{l}\text { The probability of unusual findings is } \\
\text { significant. Hence, routine HPE is } \\
\text { recommended. }\end{array}$ \\
\hline $\begin{array}{l}\text { Chandrasegaram } \\
\text { et al., } 2012 \text { [14] }\end{array}$ & Retrospective & 4,670 & $\begin{array}{l}\text { To analyze various pathologies of } \\
\text { appendix over a span of } 10 \text { years }\end{array}$ & $\begin{array}{l}\text { Worm infection and fecaliths are one of } \\
\text { the commonest usual causes of } \\
\text { appendiceal colicky pain }\end{array}$ \\
\hline $\begin{array}{l}\text { Akbulut et al., } \\
2011[1]\end{array}$ & Retrospective & 5,262 & $\begin{array}{l}\text { To address the frequency of unusual } \\
\text { findings in appendectomy samples }\end{array}$ & $\begin{array}{l}\text { Though unusual findings are quite rare still } \\
\text { it is beneficial to conduct routine HPE }\end{array}$ \\
\hline $\begin{array}{l}\text { Chamisa, } \\
2009[15]\end{array}$ & Retrospective & 371 & $\begin{array}{l}\text { To determine clinical presentations of } \\
\text { acute appendicitis and review }\end{array}$ & $\begin{array}{l}\text { Surgeons should always take into } \\
\text { consideration parasitic infections and } \\
\text { unusual causes as the reason for } \\
\text { appendicitis }\end{array}$ \\
\hline $\begin{array}{l}\text { Lohsiriwat et al., } \\
2009 \text { [16] }\end{array}$ & Retrospective & 4,545 & $\begin{array}{l}\text { To determine the impact of routine HPE of } \\
\text { surgical specimens of appendix, } \\
\text { hemorrhoids and gall bladder }\end{array}$ & $\begin{array}{l}\text { Routine HPE of appendix and gall bladder } \\
\text { specimens have shown significant } \\
\text { benefits as compared to hemorrhoids }\end{array}$ \\
\hline $\begin{array}{l}\text { In't Hof et al., } \\
2008[17]\end{array}$ & Retrospective & 1,485 & $\begin{array}{l}\text { To study the incidence and results of } \\
\text { carcinoid tumors of the appendix }\end{array}$ & $\begin{array}{l}\text { Carcinoids which are incidentally found } \\
\text { usually have a good prognosis }\end{array}$ \\
\hline $\begin{array}{l}\text { Jones et al., } \\
2007[18]\end{array}$ & Retrospective & 1,225 & $\begin{array}{l}\text { To study HPE reports of appendectomy } \\
\text { samples }\end{array}$ & $\begin{array}{l}\text { Results from HPE had a significant impact } \\
\text { on management and prognosis of the } \\
\text { patient }\end{array}$ \\
\hline $\begin{array}{l}\text { Marudanayagam } \\
\text { et al., } 2006 \text { [19] }\end{array}$ & Retrospective & 2,660 & $\begin{array}{l}\text { To analyze the usual and unusual } \\
\text { diagnosis of appendicitis }\end{array}$ & $\begin{array}{l}\text { There are a significant amount of unusual } \\
\text { pathologies, hence, favoring the policy of } \\
\text { routine HPE. }\end{array}$ \\
\hline
\end{tabular}

TABLE 1: Data from the studies with basic information regarding the number of patients, purpose and conclusion

HPE: Histopathological examination

\section{Discussion}




\section{Cureus}

The appendix is a blind-ended tube that generally sits in the lower right quadrant of the abdomen. Earlier, the appendix has been considered as a rudimentary organ and labeled "vestigial organ" (organ which has lost its function along the evolutionary pathway) until recently when a significant number of studies have shown its immunoprotective role in the intestinal immune system [20].

Pathophysiology of Acute Appendicitis

The main underlying etiology of acute appendicitis is luminal obstruction of the appendix which may be due to lymphatic hyperplasia resulting in increased intraluminal pressure leading to edema, ulceration, and inflammation which also increases its susceptibility to bacterial infections. The usual causes of acute appendicitis include fecalith and lymphatic hyperplasia. The unusual causes of appendicitis can be Infectious or Lesions (Benign/Malignant). The unusual infectious causes of appendicitis can be due to ascariasis, amebiasis, enterobiasis, actinomycosis, balantidiasis, tuberculosis, trichuriasis, or schistosomiasis [1]. Lesions such as benign neuroma, mucocele, mucinous cystadenoma, endometriosis, gastrointestinal stromal tumor, carcinoid tumors of the appendix, hyperplastic polyp, lymphoma, leukemia, granulomatous diseases, or leiomyoma can also be unusual causes of appendicitis [1].

\section{Diagnosis and Management}

Alvarado score is a clinical scoring system that takes into account six clinical features and two laboratory findings. It is a useful diagnostic score to rule out other diagnosis, however, its efficacy is inconsistent in children and overpredicts the chance of appendicitis in females. The score of 7-10 is highly suggestive and needs surgery. A score of 5-6 should not be discharged but kept in observation, however, a score of 1-4 can be discharged on the doctor's discretion [21].

Table 2 depicts the scoring criteria of Alvarado score.

\begin{tabular}{|c|c|c|}
\hline & \multicolumn{2}{|c|}{ Score Given } \\
\hline & No & Yes \\
\hline \multicolumn{3}{|l|}{ 1. Clinical Signs } \\
\hline 1.a Right lower quadrant tenderness & 0 & +2 \\
\hline 1.b Rebound pain & 0 & +1 \\
\hline 1.c Increased temperature & 0 & +1 \\
\hline \multicolumn{3}{|l|}{ 2. Symptoms } \\
\hline 2.a Anorexia & 0 & +1 \\
\hline 2.b Nausea or vomiting & 0 & +1 \\
\hline 2.c Migration of pain to the right lower quadrant & 0 & +1 \\
\hline \multicolumn{3}{|l|}{ 3. Laboratory findings } \\
\hline 3.a Leukocytosis $>10,000$ & 0 & +2 \\
\hline 3.b Shift of WBC to left & 0 & +1 \\
\hline
\end{tabular}

TABLE 2: Scoring criteria of Alvarado score

Role of Routine Histopathological Examination of Surgical Specimens

Routine HPE of a surgical specimen is generally considered beneficial as it helps to find out any unusual findings. However, due to the substantial costs of lab tests and limited resources available to the hospital, the efficacy and positive impact on the management needs to be significant to encourage routine pathological examinations.

A recent meta-analysis involving analysis of 4012 cases of acute appendicitis clearly stated that though the patients with unusual pathological findings are less (6.4\%) it is still a significant value and impacts not only the prognosis but also the management of the patient. The whole treatment plan may need to be changed in case of unusual findings and therefore, clearly recommended routine HPE for all appendectomy specimens [6]. 
Another retrospective study involving systematic review and meta-analysis of 24,697 cases found the incidence of neoplastic lesions at $0.7 \%$ and unusual pathological diagnosis in $0.9 \%$. Neoplastic lesions seen were carcinoid tumors, mucinous neoplasms, and adenocarcinoma. It concluded that though routine HPE is expensive but it is still recommended to continue doing routine histology because of a significant number of unusual diagnosis [11].

A clinical audit of a hospital in the United Kingdom on meta-analysis showed that about $1.7 \%$ of the total cases had unusual pathology other than inflammation of the appendix. These abnormal pathologies resulted in the change of the management plan of the patients. It justified doing routine HPE as there was a significant change in the management plan if unusual findings were seen [9].

To summarize, for a better holistic approach, several recent retrospective studies and meta-analysis have favored and recommended the policy of doing routine HPE of appendectomy specimens to rule out unusual pathologies.

Limitations

Even after all the accessible records available, our systematic review has some limitations. We only included literature available in the English language and excluded some abstracts for which we were unable to retrieve the full text. Non peer-reviewed articles were not included.

\section{Conclusions}

Acute appendicitis is not caused only due to a single etiology but can occur due to a variety of causes which may be parasitic infections, benign or malignant lesions. On finding unusual etiology on histopathological examination of appendectomy specimen, it usually results in changing the management plan of the patient. There is sufficient evidence suggesting various uncommon etiologies that may present as acute appendicitis in several cases. Though lab costs may be substantial and unusual findings are only seldom seen but it is still recommended to perform a routine histopathological examination of all appendectomy specimens to rule out unusual pathologies.

\section{Additional Information}

\section{Disclosures}

Conflicts of interest: In compliance with the ICMJE uniform disclosure form, all authors declare the following: Payment/services info: All authors have declared that no financial support was received from any organization for the submitted work. Financial relationships: All authors have declared that they have no financial relationships at present or within the previous three years with any organizations that might have an interest in the submitted work. Other relationships: All authors have declared that there are no other relationships or activities that could appear to have influenced the submitted work.

\section{References}

1. Akbulut S, Tas M, Sogutcu N, et al.: Unusual histopathological findings in appendectomy specimens: a retrospective analysis and literature review. World J Gastroenterol. 2011, 17:1961-1970. 10.3748/wjg.v17.i15.1961

2. Humes DJ, Simpson J: Acute appendicitis. BMJ. 2006, 333:530-531. 10.1136/bmj.38940.664363.AE

3. Snyder MJ, Guthrie M, Cagle S: Acute appendicitis: efficient diagnosis and management. Am Fam Physician. 2018, 98:25-33.

4. Dai L, Shuai J: Laparoscopic versus open appendectomy in adults and children: a meta-analysis of randomized controlled trials. United European Gastroenterol J. 2017, 5:542-553. 10.1177/2050640616661931

5. Moher D, Liberati A, Tetzlaff J, Altman DG: Preferred reporting items for systematic reviews and metaanalyses: the PRISMA statement. BMJ. 2009, 339:b2535. 10.1136/bmj.b2535

6. Elfaedy O, Benkhadoura M, Elshaikhy A, Elgazwi K: Impact of routine histopathological examination of appendectomy specimens on patient management: a study of 4012 appendectomy specimens. Turk J Surg. 2019, 35:196-201. 10.5578/turkjsurg.4253

7. Unver N, Coban G, Arıcı DS, et al.: Unusual histopathological findings in appendectomy specimens: a retrospective analysis of 2047 cases. Int J Surg Pathol. 2019, 27:142-146. 10.1177/1066896918784650

8. Dincel O, Göksu M, Türk BA, Pehlivanoğlu B, İşler S: Incidental findings in routine histopathological examination of appendectomy specimens; retrospective analysis of 1970 patients. Indian J Surg. 2018, 80:48-53. 10.1007/s12262-016-1557-z

9. Omiyale AO, Adjepong S: Histopathological correlations of appendectomies: a clinical audit of a single center. Ann Transl Med. 2015, 3:119. 10.3978/j.issn.2305-5839.2015.05.02

10. Yabanoglu H, Caliskan K, Ozgur Aytac H, Turk E, Karagulle E, Kayaselcuk F, Akin Tarim M: Unusual findings in appendectomy specimens of adults: retrospective analyses of 1466 patients and a review of literature. Iranian Red Crescent Med J. 2014, 16:e12931. 10.5812/ircmj.12931

11. Charfi S, Sellami A, Affes A, Yaïch K, Mzali R, Boudawara TS: Histopathological findings in appendectomy specimens: a study of 24,697 cases. Int J Colorectal Dis. 2014, 29:1009-1012. 10.1007/s00384-014-1934-7

12. Yilmaz M, Akbulut S, Kutluturk K, Sahin N, Arabaci E, Ara C, Yilmaz S: Unusual histopathological findings in appendectomy specimens from patients with suspected acute appendicitis. World J Gastroenterol. 2013, 


\section{Cureus}

19:4015-4022. 10.3748/wig.v19.i25.4015

13. Emre A, Akbulut S, Bozdag Z, Yilmaz M, Kanlioz M, Emre R, Sahin N: Routine histopathologic examination of appendectomy specimens: retrospective analysis of 1255 patients. Int Surg. 2013, 98:354-362.

10.9738/INTSURG-D-13-00098.1

14. Chandrasegaram MD, Rothwell LA, An EI, Miller RJ: Pathologies of the appendix: a 10-year review of 4670 appendicectomy specimens. ANZ J Surg. 2012, 82:844-847. 10.1111/j.1445-2197.2012.06185.x

15. Chamisa I: A clinicopathological review of 324 appendices removed for acute appendicitis in Durban, South Africa: a retrospective analysis. Ann R Coll Surg Engl. 2009, 91:688-692.

10.1308/003588409X12486167521677

16. Lohsiriwat V, Vongjirad A, Lohsiriwat D: Value of routine histopathologic examination of three common surgical specimens: appendix, gallbladder, and hemorrhoid. World J Surg. 2009, 33:2189-2193. 10.1007/s00268-009-0164-6

17. In't Hof KH, Van Der Wal HC, Kazemier G, Lange JF: Carcinoid tumour of the appendix: an analysis of 1,485 consecutive emergency appendectomies. J Gastrointest Surg. 2008, 12:1436-1438. 10.1007/s11605-008$0545-4$

18. Jones AE, Phillips AW, Jarvis JR, Sargen K: The value of routine histopathological examination of appendicectomy specimens. BMC Surg. 2007, 7:17. 10.1186/1471-2482-7-17

19. Marudanayagam R, Williams GT, Rees BI: Review of the pathological results of 2660 appendicectomy specimens. J Gastroenterol. 2006, 41:745-749. 10.1007/s00535-006-1855-5

20. Gebbers JO, Laissue JA: Bacterial translocation in the normal human appendix parallels the development of the local immune system. Ann N Y Acad Sci. 2004, 1029:337-343. 10.1196/annals.1309.015

21. Ohle R, O'Reilly F, O'Brien KK, Fahey T, Dimitrov BD: The Alvarado score for predicting acute appendicitis: a systematic review. BMC Med. 2011, 9:139. 10.1186/1741-7015-9-139 